2006

\title{
Does the Public Understand Intellectual Property Law? Do Lawyers?
}

David Vaver

Osgoode Hall Law School of York University, DVaver@osgoode.yorku.ca

Follow this and additional works at: http://digitalcommons.osgoode.yorku.ca/all_papers

\section{Repository Citation}

Vaver, David, "Does the Public Understand Intellectual Property Law? Do Lawyers?" (2006). All Papers. Paper 37.

http://digitalcommons.osgoode.yorku.ca/all_papers/37

This Working Paper is brought to you for free and open access by the Research Papers, Working Papers, Conference Papers at Osgoode Digital

Commons. It has been accepted for inclusion in All Papers by an authorized administrator of Osgoode Digital Commons. 


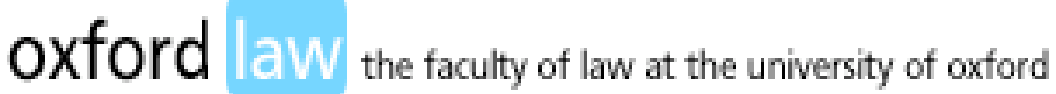

Does the Public Understand Intellectual Property Law? Do Lawyers?

DAVID VAVER

\section{DRAFT}

Keynote address, Meredith memorial lectures, McGill Law School, March 172006

\section{University of Oxford Faculty of Law Legal Studies Research Paper Series}

Working Paper No 23/2006

May 2006

This paper can be downloaded without charge from the Social Science Research Network electronic library at: http://papers.ssrn.com/Abstract $=902793$

An index to the working papers in the University of Oxford Faculty of Law Research Paper Series is located at: $<$ http://www.ssrn.com/link/oxford-legal-studies.html $>$ 
DRAFT Keynote address, Meredith memorial lectures, McGill Law School, March 172006

\title{
Does the public understand intellectual property law? Do lawyers?
}

\author{
- David Vaver ${ }^{*}$
}

I was given a speaker's dream brief: to talk about whatever I wanted so long as it had something to do with the theme of the conference - intellectual property ("IP"). A few suggestions were made in a nice, non-authoritarian way. These could, of course, have been treated the way IP lawyers usually proceed, i.e., by entirely ignoring them. That is called purposive construction, and Canadian and British courts do it all the time. So a British court has read a patent claim to say that "vertical" can also mean "leaning", a decision that comforted builders everywhere. Not to be outdone, a Canadian court last year decided, in construing a claim, that "wet" could also mean "dry". 2 Inhabitants of the Sahara might be surprised; so might those from Vancouver or San Francisco.

My subject will nonetheless be the IP system. I say the system is out of touch with both business and ordinary public sentiment, and that major rethinking and overhaul are necessary if it is to come into line. So nothing new there. But I shall not discuss particular rules as such. Instead I want to make a more basic point that lawyers tend to ignore.

We test much of our legal system and rules by asking whether they fulfil people's legitimate or reasonable expectations. How does that apply to the IP system? How does it apply, in particular, to these questions: (1) Can reasonable folk understand the system? (2) Does the way the rules are expressed make sense to them?

As my standard of the reasonable person, I shall vary (as suits) between the reasonable lawyer in her Bay Street office, the reasonable reader whose conduct the law is intending to regulate, and the reasonable judge sitting in his or her courtroom. ${ }^{3}$

\footnotetext{
Professor of Intellectual Property and Information Technology Law, University of Oxford; Director, Oxford Intellectual Property Research Centre, St Peter's College.

1 Catnic Components Ltd. v. Hill \& Smith Ltd. [1982] R.P.C. 183 (H.L.). A claim covering a structure of a lintel that was said to be "vertical" was read to include one that leaned up to 8 degrees, presumably either way.
}

2 Pfizer Canada Inc. v. Novopharm Ltd. 2005 FC 129 (Fed. Ct.). The patent claim covered making a tablet to a specified formula and dosage "by wet granulation." While the specification disclosed both wet and dry granulation processes, the court said that the skilled reader would not read the limitation "by wet granulation" as essential, so making a tablet by dry granulation infringed the patent: ibid., §§74-81\&96.

3 These are of course fictional entities. As one commuting Scottish judge recently said: "As I survey my fellow passengers on my twice weekly journeys to and from Heathrow Airport on the Piccadilly Line - such a variety in age, race, nationality and languages - I find it increasingly hard to persuade myself that any one view on anything other than the most basic issues can be said to be typical of all of them": Chester v. Afshar [2004] UKHL 41, para. 83, by Lord Hope. 
These two questions - can reasonable people understand the IP system? does the way its rules are expressed make sense to them? - are important. For if the answer to either is no, the system is not doing its job well and risks losing its moral force. Not only will it not be observed, but it may also not deserve to be observed.

Recently I heard a speaker, faced with some tough criticism of the IP system, invoke Winston Churchill: yes, he said, IP was the worst system of stimulating progress and innovation in the world - apart from all the rest. And the IP practitioners in the audience, almost unanimously, nodded or murmured their concurrence.

To admit something is bad but other things are even worse is not much of a boast. Actually, Churchill's quote was both normative and empirical. It went:

No one pretends that democracy is perfect or all-wise. Indeed, it has been said that democracy is the worst form of government except all those other forms that have been tried from time to time. ${ }^{4}$

The IP system is not perfect or all-wise, but that's too high a standard for any system. But what others have we tried from time to time? We have had patronage, prizes, subsidies, and tax write-offs as additional incentives to target innovation or dissemination in especially desirable fields; yet after we do that, we don't trim IP back in those fields, or generally. All that has occurred in the last two or three decades is that more and more activities have become protected from competition nationally and globally, and that avoiding the reach of the new protectionists has become even harder.

It is easy for specialists to get complacent, and that's true of IP. We have worked long and hard to understand the system. It is now all more or less logical to us, as were Heath Robinson's contraptions to him. True, there may be the odd quirk or two but these can be sorted out. We have committees, researchers, consultants, and whole departments of state devoted to that task. We may even get a little testy when challenged on the coherence of the system: we think it is easy for fools to criticize what they don't understand, and it is easy to equate all critics with fools.

It is true that many people do not understand the IP system except at the most abstract, and thus irrelevant, level. What is not understood is usually off-putting. It gets worse if one does understand some part of it and does not grasp why things should be so. It is hard to know which is worse: being put off by something one doesn't understand, or being put off by something one does. Let me illustrate with two cases: one Canadian, one British.

The Canadian example is the curious trade secret case that went to the Supreme Court a few years ago, Cadbury Schweppes Inc. v. FBI Foods Ltd. ${ }^{5}$ Two firms were fighting over the rights to continue making that ultimate Canadian product, clamato juice. ${ }^{6}$ The licence to use

$4 \quad$ House of Commons, 11 November 1947 (emphasis added).

5 [1999] 1 S.C.R. 142.

6 "Clamato" is not a genetically modified creature of the deep; the movie "The Attack of the Killer Clamatoes" is yet to be made. Clamato is a portmanteau word describing a mixture of tomato 
the formula ended. The licensor claimed the licensee had forever to foresake selling anything tasting like the juice because it was using the licensor's information to make it. Justice Binnie for a unanimous Court found liability but ordered the licensee to pay only damages.

The opinion is memorable for many things, not least its length. Perhaps the most memorable line is the one Justice Binnie delivered in response to the licensor's claim that the licensee had to stop making clam-tasting juice forever because the clamato information it had received was "literally, priceless", a "unique combination of elements" that was "inaccessible to the uninitiated". To which Justice Binnie replied, in words which must have struck tremors in corporate IP departments throughout the land: "Juice formulation is not rocket science."8

By definition, many things are not rocket science. Of course, Justice Binnie did not mean that. He meant that making a commercial drink from natural juices was no complicated matter. A little knowledge and experience go a long way. Perhaps even the average reasonable lawyer or judge could make such a juice at home with a bag of produce and a few experiments with a blender.

Unfortunately, the Binnie one-liner cannot be applied to IP itself. IP should not be rocket science, but unfortunately most of the time it feels as if it is. Consider Cadbury Schweppes itself. The point was simple: (a) should the licensee be stopped from making the juice; (b) if not, what (if anything) should it pay the licensor as compensation for wrongfully using the recipe? By the time the case was in the Supreme Court, liability was admitted and the facts were undisputed. So one might think: an easy case. Yet it took a judgment of over a hundred paragraphs and 60 pages in the Supreme Court Reports to decide that the licensee should not be stopped but should pay only for the headstart gained by jumping the gun. The Court did not even do the sums on damages: that was left for the trial court. Most of the judgment discussed the law and its application. It talked of English legislation from the $1850 \mathrm{~s}$, of common law and equity, of sui generis hybrids, of springboards and fusion (not nuclear). If it had suddenly speculated, with Lewis Carroll, on whether pigs had wings, would anyone have been surprised?

Here is the irony: what should be a simple case involving a simple piece of non-rocket science seems to need the legal equivalent of rocket science to resolve. ${ }^{9}$ What can one expect of cases that really do involve rocket science? If the law is this complex for lawyers and judges, how must it strike the public? How must it strike those involved not just in high

juice and clam broth. Its popularity inverts the usual trend of comparison between the Canadian and United States market: it sells at 10 times the rate in Canada than in the United States. One wonders what people do with it.

7 Economists might be intrigued by the idea that a commodity can be "literally" priceless. Eskil Ullberg, "World Trade in Intellectual Property - managing risk and uncertainty in the knowledge economy", below, proceeds on the more conventional view that everything is tradable.

8

Above note 5, at $\S 64$.

9 On the point before the court, the Supreme Court disagreed with both the trial court and the unanimous judgment of the British Columbia Court of Appeal, which itself had reversed the trial judgment. 
technology businesses but their lower-tech brethren, such as our battlers over clam juice? How can we expect businesses and the public generally to be guided by laws as complicated, as incomprehensible, as this? It is not Justice Binnie's writing or reasoning style that I am criticizing, just the legal chaos from which he sought order. This is law for the exegetical pursuits of biblical scholars, not law for $21^{\text {st }}$ century commerce, whether electronic or conventional. It costs the parties, the system, and the nation.

One may think judge-made law like that on trade secrets is the exception. Unfortunately, it is not. The situation with legislation is just as bad. At a minimum, the IP system should tell the public it serves, and the lawyers and judges who administer it, simply and clearly what qualifies for protection and how far protection reaches, i.e., what people can or cannot do. The system should do that for both specialist and non-specialist lawyers alike. It does not.

The problem is partly language. Specialists like their jargon, and lawyers are no exception. Indeed, they (together with doctors, scientists and cultural theorists) may be the paradigm jargonists.

Jargon can be efficient among the cognoscentes: a shorthand that speeds communication and understanding. It can also be a barrier. It certainly is so between lawyers and their public. It is an even bigger problem when it becomes a barrier between lawyer and lawyer - which is more often than one may think. That really is serious. If lawyers do not understand what is going on, what hope is there for non-lawyers?

Jargon is a problem for IP, particularly when one may not realize that jargon is being used. That is often true of IP laws, sometimes as written, often as interpreted. The laws are traps for public and lawyers alike.

Justice Oliver Wendell Holmes Jr was as good a thinker and user of language as anyone. He wrote some notable IP judgments. Some resonate today even beyond his native land. In a letter to Harold Laski in 1925 he wrote:

Ideas rarely are difficult to grasp. The difficulties come from the language ... To this day I am troubled as I hear arguments in patents ... cases, by the slang of the specialty. The thoughts behind the words rarely require a colossus. ${ }^{10}$

Gordon Henderson, a fine Canadian litigator in IP as well as other cases, said much the same thing. He thought IP litigation was "by and large ... the most technical both in terms of the factual subject matter and the law itself" even when compared to tax, constitutional and competition law. ${ }^{11}$ By "technical", he meant at least two things: the law was often hard to read and understand, and the results reached in any litigated dispute were also not selfevident to the reasonable Voyageur passenger, whether she had her lawyer sitting beside her or not.

10 See R.A. Posner (ed.), The Essential Holmes (1997), 52. Holmes added mining, admiralty and railroad cases to his list of horribles.

11 G. F. Henderson, Intellectual Property: Litigation, Legislation \& Education: A Study of the Canadian Intellectual Property and Litigation System (1991), 17. 
Those thoughts bring me to the English case, a simple run-of-the-mill decision. It shows how difficult many find it to understand not only what qualifies for IP protection but how far protection extends. The case involves no rocket science, just a lawyer's letter.

For the last century copyright laws have provided that an "original literary work" cannot be copied without the copyright owner's consent. One would expect most lawyers to understand how copyright law affected them in their daily office practice: is their work product especially their correspondence - protected by copyright? Do they know the position there? Is one surprised to find that some do not, including some who are not on daily first-name terms with their liability insurers?

In Musical Fidelity Ltd v. Vickers, ${ }^{12}$ Mr Vickers sold hi-fi equipment from his shop in York in the north of England. He was an authorised distributor of the "Musical Fidelity" brand until the manufacturer terminated the agreement against his will. Vickers retaliated by activating a website he had earlier created. Its domain name included the words "Musical Fidelity". He kept saying he was an authorized distributor. A lawyer's letter arrived on behalf of the manufacturer, no doubt demanding in the usual tautology that he "cease and desist" passing himself off as an authorized distributor and infringing the Musical Fidelity registered trademark. Mr Vickers posted extracts from the letter on the website, together with choice comments on them. The case came to court with a further claim: Vickers had infringed the lawyer's copyright by copying the letter on to the website.

Of course, the passing off and trademark infringement claims succeeded and were upheld on appeal. Nobody, least of all Mr Vickers, should have been surprised by that result. The copyright claim is of more interest. The trial court found for the claimant on this point too and was upheld on appeal. Two of the appeal judges were however uneasy, and said so.

Notice two oddities about the case. First, had the distributor exhibited the letter in his shop window on the busy street in York, there would have been no case on copyright. There had been no copying - and copyright is all about copying. The reasonable person or lawyer can easily understand that. If that is true, why should matters change because of the Internet? Is that not just an electronic extension of the distributor's shop window, letting more people view his wares?

The second oddity is this: What is a lawyer doing claiming copyright in a standard letter? How has copyright winkled its way into here? Do lawyers need copyright lasting a century or more, or even a day, to encourage them to write their letters? Do they write better because of copyright? Copyright can sometimes indirectly protect a person's privacy in his correspondence; but here the lawyer didn't care about privacy. The website posting gave him more publicity; the more free publicity a lawyer gets the better. Law firms have whole departments devoted to that.

It was really the manufacturer who wanted the letter and the critical comments taken down. The lawyer wasn't even a party to the case - a tricky legal point, since the claimant then had to give the court an undertaking to get in a written transfer of the copyright (which

12 [2003] F.S.R. 50 (C.A.). The case is reported only in specialist IP reports. The editors of the regular reports must have stuck their "not worth reporting, only IP" stamp on it. 
technically the lawyer owned) so that it had title to sue. The ordinary observer might find it odd that a claimant moving for summary judgment somehow missed a gap in its title. But few states have copyright registries, so titles are often obscure. Security of title in places such as Canada and the United States, which do have such registries, is little better since registration is optional and the registries present an incomplete picture of existing rights and their ownership.

The specialist lawyers had argued Musical Fidelity before a judge familiar with copyright. They spent little time on the copyright point, except to argue about whether the extracts from the letter were substantial enough to infringe. Neither the trial nor the appeal court wasted much time on that: why would the defendant bother criticizing only insubstantial parts?

The most interesting part of the case is the frank reaction of the appeal judges to the copyright claim. Lord Justice Buxton (no stranger to IP cases as an appeal judge) said he "experienced considerable surprise" to discover (1) that a solicitor's ordinary letter was an "original literary work" and could have copyright at all, and (2) that a recipient then infringed by copying the letter. ${ }^{13}$ Lord Justice Wall added his own bon mot on the "vexed question of copyright":

I too was surprised that copyright attached to solicitors' correspondence (though one knows, having read bundles of solicitors' correspondence, that they might sometimes justify being called literary works of fiction). ${ }^{14}$

They were surprised; imagine the reaction of the shop owner from York.

It is revealing to find senior judges with decades of legal practice between them in diverse fields, who have handled thousands of lawyers' letters in their time, frankly confessing themselves ignorant of matters that appear elementary to specialist IP lawyers. Legal practice must have got along well enough in the past without lawyers needing to run to the Copyright Act to protect themselves.

Look at the problem the Musical Fidelity case posed for the judges. They turn to the copyright statute. It plainly says there is copyright in an "original literary work." 15 How does one get from that to protecting a lawyer's ordinary letter?

13 In Tett Bros. Ltd. v. Drake \& Gorham Ltd. [19281935] MacG. Cop. Cas. 492 (Ch., 1934) copyright in the following masterpiece (omitting "Dear Sir" and "Yours etc.") was held to be infringed:

Further to the writer's conversation with you of to-day's date, we shall be obliged if you will let us have full particulars and characteristics of "Chrystalite" or "Barex." Also we shall be obliged if you will let us have your lower prices for 1, 2, 3, 4 and 5 ton lots and your annual contract rates.

We have been using a certain type of mineral for some time past and have not found it completely satisfactory, and as we shall be placing an order in the very near future we shall be obliged if you will let us have this information at your earliest convenience.

14 The presiding judge, Lady Justice Arden, had previously sat in the Chancery Division on her fair share of copyright cases and seemed unbemused by this one. She did note that no point on originality had been taken before the trial court and so was not open on appeal. 
One turns to the books and cases to find quickly that "original" doesn't mean "novel" (although that's one of its ordinary meanings); in copyright jargon, it just means that the item isn't copied and some mental skill or judgment went into its composition. (How much is something to argue about: Americans may differ from Canadians on this, and Canadians may even differ from the British). Where everybody agrees is that two identical works can be original if neither is copied from the other. ${ }^{16}$

One then learns that "literary" doesn't mean "literary", at least not in the sense of Dickens or Attwood, or Dan Brown (barely). Even a computer program can be "literary" although nobody can read or even see it in its electronic form; and if it is seen in a print-out, it is not read as literature unless the reader is demented, or a software coder, or also enjoys reading telephone directories. "Literary" here just means expressed in conventional symbolic form using letters and figures.

What of the word "work" in "original literary work"? Here "work" does not mean that much or any work had to be spent on it. We could substitute something like "thingummy" in the Act instead of "work" and lose nothing in meaning.

But that is just a start. Turn to the case law and one finds the phrase "original literary work" can mean more or less than the sum of each of "original" and "literary" and "work". 17 Defying mathematics, in law $1+1+1 \# 3$ or $\exists 3$. The phrase is an exocentric compound: the concept created by the three words differs from the words taken singly, just as "dumbbell", in either of its senses - a weight for lifting or an idiot - does not mean a "dumb bell", a mute cast-iron object with a clapper that for some reason cannot or will not be made to ring.

There's more. A recent case in the Canadian Supreme Court on original literary work holds that headnotes in law reports qualify. ${ }^{18}$ The court says nothing about letters of lawyers or anybody else; but if a headnote, that is written after someone reads a case and boils it down to its essentials, qualifies as an original literary work, a letter written after a lawyer has digested the relevant facts from what her client tells her, and worked out what to tell the other side, should qualify. Both products may be brief; but legal brevity shouldn't be discouraged by denying copyright to its result, at least if the writer says something beyond "Stop using our client's name, you rogue, or else" (although even that formula may have a certain pithiness worth encouraging).

There is a certain internal logic to all this but - and this is my point - not one that is selfevident to any reasonable person or non-specialist lawyer reading the Act, even with the best will in the world. The logic sidesteps larger normative questions: Should lawyers' letters have copyright? If so, should lawyers be allowed always to claim copyright in them, or

15 Copyright, Designs and Patents Act 1988 (U.K.), s. 1(1) \& 3(1); similarly, Copyright Act R.S.C. 1985 , c. C-42, s. 5(1).

See Abraham Drassinower, “Origins of Knowledge: Creation vs. Evolution”, below. 
should they sometimes be barred from doing so on public policy grounds? Should clients, when the lawyer transfers the copyright to them at their behest, get better rights than the lawyer? Should they be stopped from enforcing the copyright on the same grounds as the lawyer? Apart from issues of professional ethics, what would the reasonable passenger on the Voyageur bus say?

Why should copyright stop Vickers from putting the letter on a website, and criticizing it there? In some places it would not. In the United States, if there is copyright in the letter, Vickers' act would probably be a fair use and not an infringement. One might even haul out the First Amendment if all else fails.

Elsewhere Vickers would have more difficulty because the copyright laws, as written, give users little leeway. He would probably be safe in Canada; the Act provides that "fair dealing for the purpose of criticism" does not infringe copyright if the author's name and source are also mentioned. ${ }^{19}$ So Vickers could upload his letter in Canada so long as he added some criticism, put up no more than necessary for his criticism, and included the source of the letter and the author's name (which were probably evident from the letter itself). Since the date that Musical Fidelity was decided, an amendment to UK law, required by a European Directive, restricts fair dealing for criticism to cases where the work is "made available to the public" with the copyright owner's consent. Fair critical dealing with ordinary letters no longer exists in Europe except where only an insubstantial part of the letter is quoted. ${ }^{20}$

An impartial observer might ask: why all this rigmarole? Why must Vickers criticize to get the right to publicize a letter? Why can't he say alongside the upload: "Look what these scoundrels are trying to do to me"? Will that do as "criticism"? Probably not. Even if it did, an unhelpful statement from the leading British case says that the comment may not qualify as "fair dealing" because it's too short: "To take long extracts and attach short comments may be unfair. But, short extracts and long comments may be fair." ${ }^{21}$ So be cryptic, and be sued; be long-winded, and be immune.

It's precisely at this point that the "considerably surprised" judge in Musical Fidelity seems to have lost patience. He said:

19

Copyright Act, R.S.C. 1985, c. C-42, s. 29.1.

20 Copyright, Designs and Patents Act 1988 (U.K.), ss. 30(1) \& (1A), as am. in 2003, implementing art. 5(3)(d) of the EU Directive 2001/29/EC of 22 May 2001 on the harmonisation of certain aspects of copyright and related rights in the information society. See now HRH Prince of Wales v. Associated Newspapers Ltd [2006] EWHC 522 (Ch.), so holding in relation to Prince Charles' private journals; see further note 22 below on a possible free expression defence.

What amounts to an insubstantial part of a work can be controversial: see the 3:2 division among Copyright Board members in Breakthrough Films \& Television's Licence application (No. 2004-UO/TI-33, 6 March 2006) on 8 isolated passages taken from an autobiography for use in a film documentary. The joint dissent of Vancise JA and Mr Callary is particularly noteworthy.

Hubbard v. Vosper [1972] 2 Q.B. 82, 94 (C.A.); see also Zamacois v. Douville [1944] Ex.C.R. 208 (reproduction in a Quebec paper of an entire article taken from a French paper infringes copyright; implied criticism does not invoke a fair dealing defence). 
That issue [i.e., infringement] is, in my judgment, not best resolved by applying to it the narrow copyright law on fair dealing. That is an impoverished means of considering these questions, because it is principally directed at dealings with works which are "literary" in the real sense, and not in the sense that the law of copyright uses to describe these particular letters as literary works.

Should this matter arise in the future, it might well be wise to consider whether, when a person causes his solicitor to write a letter of this sort, he is not giving an implied consent to its publication by the recipient that goes more widely than the very narrow limits that apparently are presently recognised by the law of copyright. That consideration might well be further informed by reflecting on the position of this part of the law of copyright in relation to Art.10 of the European Convention on Human Rights [i.e., the right of freedom of expression]. ${ }^{22}$

This approach follows a long tradition where judges feel duty-bound to try to avoid an apparent injustice caused by the mechanical application of a poorly expressed or conceived statute.

What broader lessons do the Cadbury Schweppes and Music Fidelity cases teach us about IP law as it currently stands?

First, from Cadbury Schweppes we learn we must stop regulating IP rights through common law, equity or faute, except as a last resort. We know enough about commercial confidence and trade secret law to legislate for it. In 1987 the Uniform Law Conference of Canada produced a Uniform Trade Secrets Act modelled on a United States counterpart. No province enacted it. The Conference is updating its draft and trying again to kindle interest in the provinces. One wonders who is resisting. Surely not the lawyers, even though many prefer their law ancient, common and expensive. Surely not industry: if it is, it has to be told that trade secret law, like juice formulation, need not be rocket science.

Secondly, legislation is no answer in itself, as Musical Fidelity reveals. The legislation must hit its target precisely and clearly. Karl Llewellyn said that the "rightist and most beautiful type of legal rule [is] the singing rule with purpose and with reason clear." "23 Many IP rules don't sing; when they do, they sound like Florence Foster Jenkins. The judges in Musical Fidelity were right: the law was off-key. Privacy law already aptly regulates the disclosure of letters. It needs no help from copyright. Client letters do not belong in the Copyright Act. Walter Scott, novelist, may need encouragement to write Ivanhoe; Walter Scott, lawyer, needed no encouragement to write client letters. Much IP law comes from the sort of sloppy thought which says that because one class of work needs encouragement, another one that looks a bit like it should too. So computer code gets lumped in with novels and accounting forms and lawyers' letters and logarithm tables and statutes and haiku and lottery tickets and

$22 \quad$ Musical Fidelity, note 12 above, at $\S \S 29-30$, nevertheless dismissing the copyright appeal since these points were not taken before the lower court or argued on appeal. Article 10 of the Human Rights Convention has become even more important in Europe given the new restrictions on use required by the EU information society directive, above note 20 .

23 K.N. Llewellyn, "On the Good, the True, the Beautiful, in Law", 9 Uni. Chicago L. Rev. 224, 250 (1941). 
private diary entries: all "original literary works". What evidence is there - was ever there that this miscellany of matter needed and deserved protection from copying, and then for up to a century or more? Mostly, nothing.

Thirdly, if one doesn't know what one is protecting and why, one cannot ex ante have any idea how far protection should run. IP laws are used to make threats and people cave in, depending on who has money and power on their side and whether they think it is worth making an issue. When an odd case rumbles into court, the judges make law on the trot, as in Musical Fidelity. Nobody had expressly consented to the uploading there; so the court suggested they might impliedly have consented. Perhaps the lawyer would not have cared about the disclosure, but the client surely did: which makes it a difficult case to imply consent in fact or law. So one may end up with the fiction of consent, returning to days of John Doe and Richard Roe. If implied consent doesn't work, the spare sledgehammer of human rights law can be brought out to crack the nut - all because a copyright law which is about protecting expression forgets to protect the expression of everyone except the little class it designates as authors and their employers and publishers.

Legislatures owe a public responsibility under the Rule of Law principle: (1) to draft clearly, targeting precisely what deserves protection; (2) to provide a broad defence for the unexpected or unforeseen cases that arise from the grant of unexpected, unforeseen, and probably unnecessary protection. The case for a "fair use" defence at least as broad as that in the United States seems unanswerable, if only to deal with such cases.

Fourthly, if it is so hard to figure out liability in IP cases, how is it right to hit infringers as hard as we do, especially in Canada? Liability for IP infringement, as written or interpreted, is generally strict: the defendant infringes whether he knows or intends it or not. The claimant is then awarded generous compensation for foreseeable losses, on standard tort principles. $^{24}$ That position needs rethinking. Ignorance of the law may not excuse but at least it should mitigate. Other countries' laws do that; international law permits it.

Fifthly, it is difficult to know not only what is protected and how far but also, as Musical Fidelity shows, who owns what. The court hearing is proceeding as usual when suddenly someone discovers the wrong person is in court claiming the rights. Musical Fidelity is no aberration. Registers, where they exist, often tell misleading stories. ${ }^{25}$ When title is uncertain, buyers and lenders shy away. ${ }^{26}$ In 2004 the Law Commission of Canada said

\section{Gerber Garment Technology Inc. v. Lectra Systems Ltd. [1997] R.P.C. 443 (C.A.).}

25 In Canada an unregistered patent assignee or licensee has title to sue: Apotex Ltd. v. Wellcome Foundation Ltd. (2000), 10 C.P.R.(4th) 65, 93 (Fed. C.A.). So in the UK does an unregistered claimant who acquires its patent by operation of law, despite an apparently more comprehensive patent register: Tamglass Ltd Oy v. Luoyang North Glass Technology Co. Ltd [2006] EWHC 445 (Ch.) (title passing to claimant under Finnish law of corporate merger and demerger).

26 See further, Catherine Walsh, "Mobilisation of Intellectual Property in Secured Financing: Intelligent Design in a Transsystemic World", below. 
something had to be done about title security if IP was to attract quality financing. ${ }^{27}$ So far, nothing has happened.

Ultimately, "non-singing" laws cause harm. In concluding my inaugural lecture at Oxford some years ago, I said:

...[F]or the intellectual property system to survive, it must gain and keep public respect. To be respected, it must be known. To be known, it must be understood. To be understood, it must be coherent and persuasive. There are now calls that the public should become better educated about intellectual property. Such calls are, naturally, music to the ears of any educator. But one must be prepared for the consequence that an educated public is entitled to demand greater coherence and persuasiveness from the intellectual property system than that system presently exhibits. If those calls are not met and answered, then greater knowledge will not produce greater public respect, but instead cynicism, disregard and avoidance. ${ }^{28}$

I thought that then. I think that now.

27 Law Commission of Canada, Leveraging Knowledge Assets: Reducing Uncertainty for Security Interests in Intellectual Property (2004). 